\title{
SPATIAL AND TEMPORAL VARIABILITY OF SURFACE TEMPERATURE, LAND USE AND LAND COVER CHANGE: A CASE STUDY IN CAMPINAS, BRAZIL
}

\author{
BEZERRA, Luiza Marchezan - luiza.bezerra04@gmail.com \\ Universidade Estadual de Campinas / UNICAMP
}

AVILA, Ana Maria Heuminski - avila@cpa.unicamp.br

Universidade Estadual de Campinas / UNICAMP

Submetido em: 09/05/2020

Aceito para publicação em: 26/04/2021

Publicado em: 28/04/2021

DOI: http://dx.doi.org/10.5380/abclima.v28i0.73611

\begin{abstract}
The deteriorating climatic conditions in Brazilian urban centers is a real concern for human security and urban livelihood sustainability. The city of Campinas in São Paulo, Brazil, is highly vulnerable to climatic disasters. This paper analyzes the relation between land use changes and temperature in Campinas between 1989 and 2016. The 28-year period was chosen due to the variability of climatic data in three meteorological stations (University of Campinas, Agronomic Institute of Campinas and International Airport of Viracopos). Data from five sources were used for analysis of land use and land changes (LULC), and of land surface temperature (LST). The data sources were: i) Landsat 5 Thermometer Mapper (TM), ii) Landsat 5 Thermal Infrared Sensor (TIRS), iii) Thermal Infrared Sensor (ETM +) sensors from Landsat 5, iv) Landsat 8 Operational Land Imager (OLI), and v) Thermal Infrared Sensor (TIRS). The results indicate consistent relations between urbanized increase area and the elevation of air and surface temperature in Campinas. In the studied period, there was an increase of $23 \%$ in urbanized areas and around the meteorological stations. The Center for Meteorological and Climatic Research Applied to Agriculture at the University of Campinas (CEPAGRI/UNICAMP) presented the highest growth measure, about $22 \%$, as well as the station with the highest air temperature.
\end{abstract}

KEYWORDS: Urban Climate, Remote Sensing, Land Use, Surface Temperature

VARIABILIDADE ESPACIAL E TEMPORAL DA TEMPERATURA DA SUPERFÍCIE, MUDANÇA NO USO E COBERTURA DO SOLO: UM ESTUDO DE CASO EM CAMPINAS, BRASIL

RESUMO: A deterioração das condições climáticas nos centros urbanos do Brasil é uma preocupação real para a segurança humana e a sustentabilidade dos meios de subsistência urbanos. A cidade de Campinas no estado de São Paulo, Brasil é altamente vulnerável a desastres climáticos. O presente trabalho analisa a relação entre mudanças de uso do solo e temperatura em Campinas entre 1989 e 2016. O período de 28 anos foi escolhido devido à disponibilidade dos dados climáticos em três estações meteorológicas (Universidade de Campinas, Instituto Agronômico de Campinas e Aeroporto Internacional de Viracopos). Dados de cinco fontes foram usados para análise de mudanças no uso do solo (LULC) e temperatura da superfície da terra (LST). As fontes de dados foram: i) Landsat 5 Thermometer Mapper (TM), ii) Landsat 5 Sensor infravermelho térmico (TIRS), iii) sensores infravermelhos térmicos (ETM +) do Landsat 5, iv) Landsat 8 Operational Land Imager (OLI) ev) Sensor infravermelho térmico (TIRS). Os resultados indicam relações consistentes entre o aumento da área urbanizada e a elevação da temperatura do ar e da superfície em Campinas. No período estudado, houve um aumento de $23 \%$ nas áreas urbanizadas de Campinas e no entorno das estações meteorológicas. O Centro de Pesquisas Meteorológicas e Climáticas Aplicadas à Agricultura (Cepagri) apresentou o maior crescimento, cerca de $22 \%$, assim como a estação com maior temperatura do ar.

PALAVRAS-CHAVE: Clima Urbano, Sensoriamento Remoto, Uso da Terra, Temperatura de Superfície. 
VARIABILIDAD ESPACIAL Y TEMPORAL DE LA TEMPERATURA DE SUPERFICIE, CAMBIO EN EL USO Y COBERTURA DEL SUELO: UN ESTUDIO DE CASO EN CAMPINAS, BRASIL

RESUMEN: El deterioro de las condiciones climáticas en los centros urbanos de Brasil es una preocupación real para la seguridad humana y para los medios de vida sostenibles. La ciudad de Campinas en el estado de São Paulo, Brasil, es altamente vulnerable a los desastres climáticos. El presente trabajo analiza la relación entre los cambios de coberturas y uso del suelo y la temperatura en Campinas entre 1989 y 2016 . Se selecionó el período de 28 años debido a la disponibilidad de datos climáticos en tres estaciones meteorológicas (Universidad de Campinas, Instituto Agronómico de Campinas y Aeropuerto Internacional Viracopos). Se utilizaron datos de cinco fuentes para analizar los cambios en el uso de la tierra (LULC) y la temperatura de la superficie de la tierra (LST). Las fuentes de datos fueron: i) Landsat 5 Thermometer Mapper (TM), ii) Landsat 5 Thermal infrarrojos (TIRS), iii) Landsat 5 , sensores térmicos infrarrojos (ETM +), iv) Landsat 8 Operational Land Imager (OLI) yv) Sensor térmico infrarrojo (TIRS). Los resultados indican relaciones consistentes entre el aumento en el área urbanizada y el aumento de la temperatura del aire y de la superficie en Campinas. Durante el período estudiado, hubo un aumento del $23 \%$ en las áreas urbanizadas de Campinas y alrededor de las estaciones meteorológicas. El área en la que se ubica el Centro de Investigaciones Meteorológicas y Climáticas Aplicadas a la Agricultura (CEPAGRI) mostró el mayor crecimiento, en torno de $22 \%$, así como la mayor temperatura del aire registrada en su estación meteorológica.

PALABRAS CLAVE: Clima urbano, teledetección, uso del suelo, temperatura de la superficie.

\section{INTRODUCTION}

Campinas has witnessed a rapid growth in industrial activities since the early seventies (CAIADO and PIRES, 2006). The city's industrialization has attracted an intense migratory flow with haphazard urban expansion (PEZZUTO, 2007). The rapid social and environmental transformations without the necessary infrastructures to mitigate the intense urban sprawl exposed the population to areas of great risk for climatic disasters, such as floods, mudslides, and landslides (VOOGT and OKE, 2002; VOOGT and OKE, 1998; CAVALCANTI et al., 2017).

The rapid spatiotemporal changes in patterns of land use and occupation caused by the intense urbanization process correspond to the main impacts of anthropic actions on the natural system (OLIVEIRA et al., 2013), contributing to the accentuation of heat emissions, land use and land cover (LULC) changes (LO and QUATTROCHI, 2003; FU and WENG, 2016; RODRIGUES et al., 2017). The urban sprawl influences the modification of latent and sensitive heat flux to the detriment of the water content in the soil, and the vegetation present in the studied/project area (ARNFIELD, 2003; CHEN et al., 2006; WENG et al., 2004; RODRIGUES et al., 2017).

The urban climate resulting from the different spatial arrangements may be understood by an analysis of the physical properties of the surface (ZHOU et al., 2011). Among these, the temperature is an important variable for understanding atmospheric processes that occur inside urban climates, such as heat islands, generation of wind currents or concentration of air pollution (ZHU and WOODCOCK, 2014; OKE et al., 2017; RODRIGUES et al., 2017).

The city of Campinas (Figure 1 ) is located in the Southeast region of Brazil, state of São Paulo, in the Latitude 22 $53^{\prime} 20$ "S and Longitude $47^{\circ} 04^{\prime}$ 40" W (CAMPINAS, 2016). 

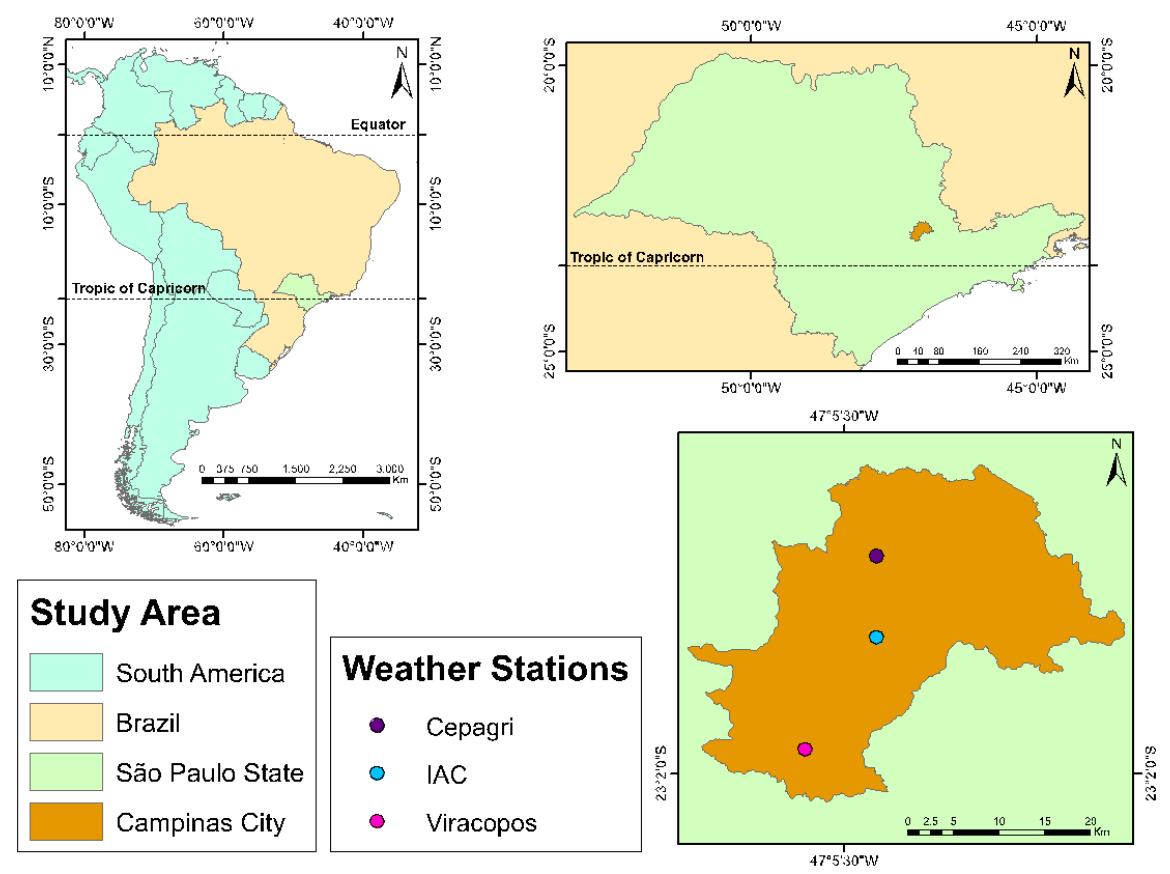

Figure 1- Location of Campinas in São Paulo state.

Campinas is located in a transition area between the tropical and subtropical climate (Cwa, according to Köepen classification) with an annual average temperature of $21.6^{\circ} \mathrm{C}$ (BECK et al.,2018). The mean temperature in the hottest months (November to February) is higher than or equal to $22^{\circ} \mathrm{C}$, and in the coldest months (May to August) lower than $18^{\circ} \mathrm{C}$. The mean annual precipitation is $1.381 \mathrm{~mm}$ with the rainy period from October to March, and the dry period from April to September, presenting a precipitation rate of less than $30 \mathrm{~mm}$ (BLAIN, 2009). Campinas is about $150 \mathrm{~km}$ from the ocean, and the precipitation regime is strongly characterized by seasonal contrast. The summer is the rainiest period due to a series of atmospheric processes that contribute to the increase of humidity caused by the South Atlantic Convergence Zone (SACZ) (CAVALCANTI et al., 2017: DIAS et al., 2013).

According to the Brazilian Institute of Geography and Statistics, IBGE (2017), Campinas has 1.180,429 inhabitants, being the fourteenth most populous city in Brazil (IBGE, 2018) with a population density of 1,372 inhabitants $/ \mathrm{km}^{2}$, and approximately $98 \%$ urbanization degree. It occupies a total area of $794.40 \mathrm{~km}^{2}$ (urban perimeter of $388.90 \mathrm{~km}^{2}$ and rural perimeter of $407.50 \mathrm{~km}^{2}$ ) with an average height of 680 meters above sea level. The city is the eleventh largest economy in Brazil, responsible for about 0,95\% of the entire national economy (IBGE, 2017). Its diversified industrial center covers around $10 \%$ of all Brazilian industrial production, agriculture, and services (CAVALCANTI et al., 2017; CASTELLANO, 2010). Also, Campinas is the center of the Metropolitan Region that stands out in the national and regional scenario as a reference for research and development of science, technology and innovation (CASTELLANO, 2010; PEZZUTO, 2007: CAIADO and PIRES, 2006).

The present article seeks to analyse the changes in land use and land cover (LULC) in Campinas in 1989 and in 2016, and the relation with air and surface temperature. We used data generated by the maximum number of 
scientifically recognized climatic data stations to study the time and space variability. The stations cover a large area of the city as they are located at the Center for Meteorological and Climatic Research Applied to Agriculture at the University of Campinas (CEPAGRI/UNICAMP), at the Agronomic Institute of Campinas (IAC), and at the International Airport of Viracopos.

\section{MATERIAL AND METHODS}

The LULC classification and surface temperature estimates use remote sensing techniques to carry out analysis about the evolution of land use, land occupation, and surface temperature in Campinas.

Two satellite images were obtained, both comprising the entire Campinas region. One 14 August 1989, of the Landsat 5 satellite Thematic Mapper (TM), Enhanced Thematic Mapper Plus (ETM +) and thermal infrared (TIR) data with 30 meters and 120 meters spatial resolution. The other, on 09 September 2016, of the Landsat 8 satellite Operational Land Imager (OLI) and Thermal Infrared Sensor (TIRS) data with 30 meters and 100 meters spatial resolution. The Landsat 5 image was downloaded from the National Institute for Space Research (INPE, 2015) website and the Landsat 8 image was downloaded from the United States Geological Survey (USGS, 2016) website, respectively.

Satellites are the only way to estimate surface temperature with high spatial(meters) and temporal(minutes) resolution (AZEVEDO et al. 2016). The data estimated by satellite may be used to compensate and complement the low availability of data from meteorological stations. The weather stations collect air temperature data, that is, they cannot collect surface temperature. At the same time, satellite images do not collect air temperature near the surface. Both methodologies, then, are complementary to climatology studies. The use of satellite bands in the thermal infrared region allows capturing the electromagnetic energy of objects with a temperature above absolute zero. Therefore, all landscape elements, whether urban or natural, may be portrayed in a satellite image through its emitted thermal energy (WENG and YANG, 2004; DASH et al., 2002; RODRIGUES et al., 2017).

\subsection{CLASSIFICATION}

The images were submitted to the unsupervised classification tool Iso Cluster, on the ArcGis. It is made by an automatic class generation processing, conducted utilizing spectrally close pixel groups (ANDRADE et. al., 2014). Four classes were used (Table 1), based on the land use classification system, proposed by IBGE (2013).

Table 1 - Types of Classes for the development of different uses and land cover.

\section{Class} Description 


\begin{tabular}{ll}
\hline & $\begin{array}{l}\text { structured by buildings and road systems } \\
\text { where non-agricultural artificial surfaces } \\
\text { predominate }\end{array}$ \\
\hline Natural Vegetation & This class comprises a set of forest and \\
& grassland structures, ranging from forests and \\
& original (primary) fields to spontaneous \\
& secondary forest formations, shrubs, \\
& herbaceous, and/or grassy-woody. \\
\hline Rural Vegetation & Different categories of vegetation \\
& physiognomically different from the forest, \\
& characterized by a predominantly shrubby \\
& stratum, sparsely distributed on a grassy- \\
& woody carpet. \\
Exposed Soil & Anthropic environments, with exposed soil \\
& resulting from degradation caused by human \\
activities.
\end{tabular}

\subsection{ESTIMATION OF LAND SURFACE TEMPERATURE}

To estimate the land surface temperature, thermal infrared bands were collected from sensors TM from Landsat 5 on August $14^{\text {th }}, 1989$ and TIRS from Landsat 8 on September $09^{\text {th }}, 2016$, respectively.

For the year 1989, the used thermal image was from band 6 (present in Landsat 5 satellite), in which formulas were applied to three stages:

\section{a) Conversion of gray level values from band 6 in spectral radiance} by the spectral radiance scaling method:

$\mathrm{L} \lambda=((\operatorname{LMAX} \lambda-\operatorname{LMIN} \lambda) /(\mathrm{QCALMAX}-\mathrm{QCALMIN})) *(\mathrm{QCAL}-\mathrm{QCALMIN})+\mathrm{LMIN} \lambda$

Where:

$\mathrm{L} \lambda=$ Radiance of the thermal band

LMAX - LMIN = Spectral radiance parameters for each band

QCALMAX = Maximum gray level to be calibrated (Landsat $=255$ )

QCALMIN = Minimum gray level to be calibrated $($ Landsat $=1)$

$\mathrm{QCAL}=$ Gray level of each pixel

Therefore, $L \lambda$ is the top-of-atmosphere (TOA) radiance at the sensor's aperture in W/ ( $\mathrm{m}^{2}$.sr. $\left.\mu \mathrm{m}\right)$, QCALMAX and QCALMIN are the highest and lowest points of the rescaled radiance range in DN, LMIN and LMAX are the TOA radiances that are scaled to QCALMIN and QCALMAX (YUAN and BAUER, 2006).

b) Conversion from spectral radiance to surface temperature, where the imaged Earth Surface assumes unity emissivity:

$\mathrm{T}=\mathrm{K} 2 / \mathrm{In}(\mathrm{K} 1 / \mathrm{L} \lambda+1)$

Where:

$\mathrm{T}=$ Effective at-satellite temperature in $\mathrm{K}$

$\mathrm{K} 2$ = Calibration constant 2 in $\mathrm{K}$

$\mathrm{K} 1$ = Calibration constant 1 in $\mathrm{W} /\left(\mathrm{m}^{2}\right.$.sr. $\left.\mu \mathrm{m}\right)$ 
$\mathrm{L} \lambda=$ Spectral radiance at the sensor's aperture

Therefore, $\mathrm{T}$ is the temperature in Kelvin (K), $\mathrm{K} 1$ is the pre-launch calibration constant 1 in $\mathrm{W} /\left(\mathrm{m}^{2} \mathrm{sr} \mu \mathrm{m}\right)$, and $\mathrm{K} 2$ is the pro-launch calibration.

For the year 2016, the used image was generated by the composition of thermal bands 10 and 11 (present in Landsat 8). The image was submitted to the Radiometric calibration tool, present at digital geoprocessing software Envi IDL.

\subsection{SETTING THE MAXIMUM AIR TEMPERATURE THRESHOLDS}

The values were calculated for each station individually. The annual maximum temperature values were obtained, and the ranges between the maximum and minimum values were established for the three stations.

\section{RESULTS AND DISCUSSION}

\subsection{MAPPING THE LULC}

The results present the LULC in the city of Campinas and the LULC of the surrounding area within a 2.5-kilometer radius for each meteorological station of the city.

\section{a) LULC in the city of Campinas}

Figure 2 shows the evolution of LULC for the entire city of Campinas. The increase of urban areas is significant between 1989 and 2016. According to Table 3, the urbanized area more than doubled, from $20,2 \%$ in 1989 to $43 \%$ in 2016.

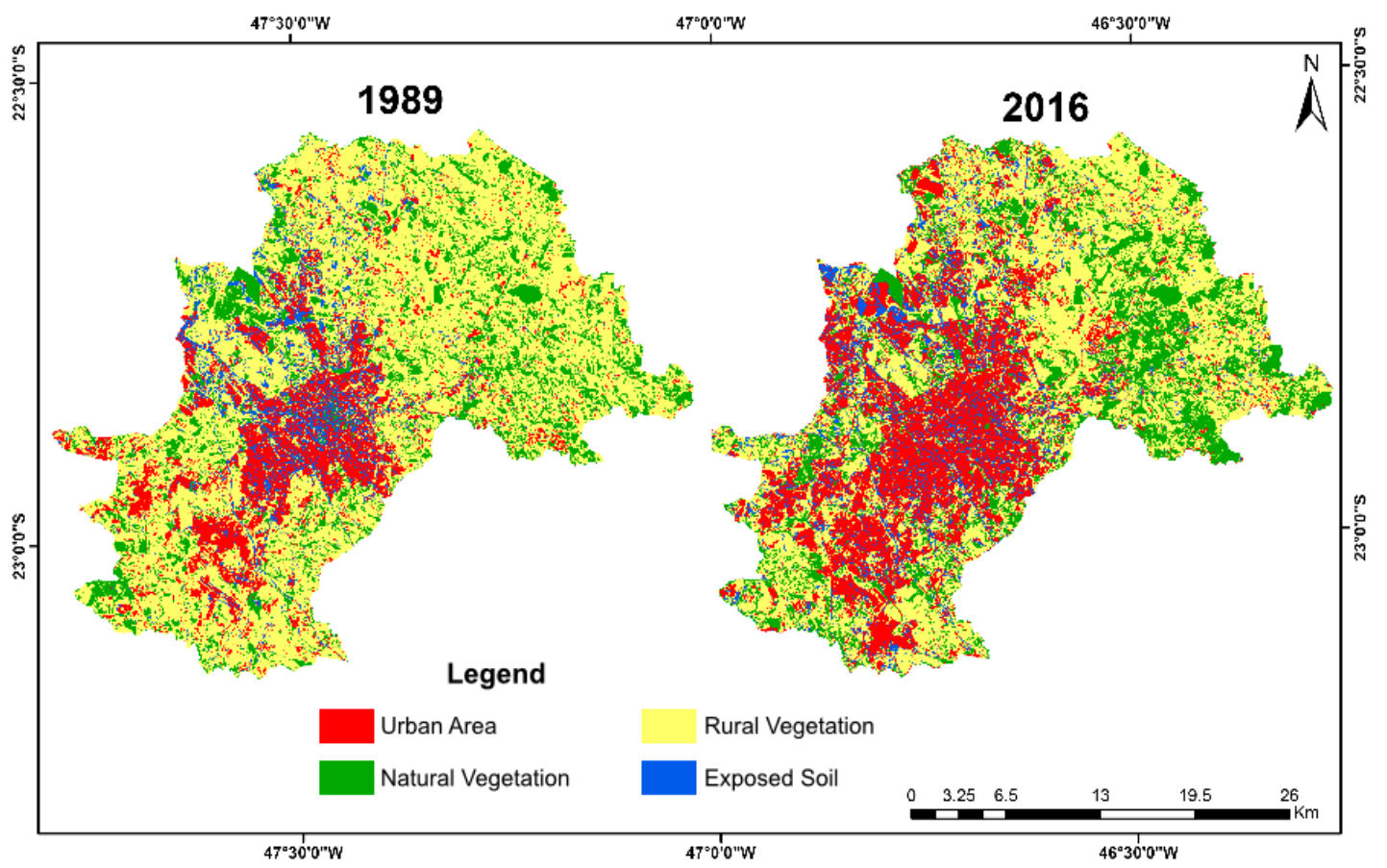


Figure 2 - Map of spatial variability of land use in Campinas on August 14th 1989 and September 09th 2016.

Table 2 - Land use in Campinas in percentage (\%), in 1989 and 2016

\begin{tabular}{ccc}
\multicolumn{3}{c}{ Campinas } \\
\hline Class & 1989 & 2016 \\
\hline Urban Area & 20,2 & 43,0 \\
\hline Natural Vegetation & 14,2 & 13,3 \\
\hline Rural Vegetation & 60,2 & 37,8 \\
\hline Exposed Soil & 5,3 & 5,6 \\
\hline
\end{tabular}

\section{b) LULC in Campinas weather stations}

Table 3 presents the obtained results about the evolution of LULC of the surrounding area within a 2.5-kilometer radius for each meteorological station in Campinas in 1989 and 2016.

Table 3 - Land use in the weather stations in percentage (\%) at a radius of 2,5 km in 1989 and 2016.

\begin{tabular}{lllllll}
\hline Classes & Cepagri & \multicolumn{3}{c}{ IAC } & \multicolumn{3}{c}{ Viracopos } \\
\cline { 2 - 7 } & 1989 & 2016 & 1989 & 2016 & 1989 & 2016 \\
\hline Urban Area & 10,3 & 32,0 & 16,7 & 27,0 & 13,9 & 27,7 \\
\hline $\begin{array}{l}\text { Natural } \\
\text { Vegetation }\end{array}$ & 44,2 & 5,4 & 5,4 & 35,9 & 33,8 & 32,5 \\
\hline Rural Vegetation & 39,2 & 38,0 & 42,7 & 31,4 & 24,7 & 15,8 \\
\hline Exposed Soil & 6,1 & 24,4 & 35,1 & 5,5 & 27,5 & 23,8 \\
\hline
\end{tabular}

The distribution pattern of urbanized areas changed between 1989 and 2016. The population growth has evidenced a new process of urban distribution since 1990 (CAVALCANTI et al., 2017), which is associated with significant changes in urban structure, expressed by economic and residential activities, interurban displacements, and changes in land use and occupation. The results show a gradual increase in the infrastructure of the current urban system for the years studied. The urban area around Cepagri station went from 10,3\% of the total area in 1989, to $32 \%$ in 2016 . For IAC and Viracopos regions, the rate rose from $16,7 \%$ to $27 \%$ and from $13,9 \%$ to $27,7 \%$, respectively, between 1989 and 2016. Thus, the dynamics of urban area expansion was higher around Cepagri and Viracopos stations, while IAC station recorded vegetation cover increase.

\subsection{MAPPING SPATIAL VARIABILITY OF SURFACE TEMPERATURE IN CAMPINAS}

Figure 3, represented by the spatial channel of the Landsat 5 and Landsat 8 satellites, shows the spatial variability of surface temperature in Campinas on August 14th 1989 and September 09th 2016, respectively. Temperatures ranged from below $18^{\circ} \mathrm{C}$, in green, to high temperatures above $30^{\circ} \mathrm{C}$, in red. The central and southern regions, where IAC and Viracopos stations are located, respectively, are the most urbanized areas. On September 09th 2016, the surface temperature increased when compared to the August 14th 1989. However, at Cepagri station area the temperatures were above $30^{\circ} \mathrm{C}$ in 1989, showing predominantly reddish colors, and changed to orange and 
yellow in 2016 , corresponding to temperatures between $30^{\circ} \mathrm{C}$ and $24^{\circ} \mathrm{C}$. The temperature reduction may be due to the fact that the station was moved 500 meters from an experimental area with construction expansion to a greener area near Cepagri.

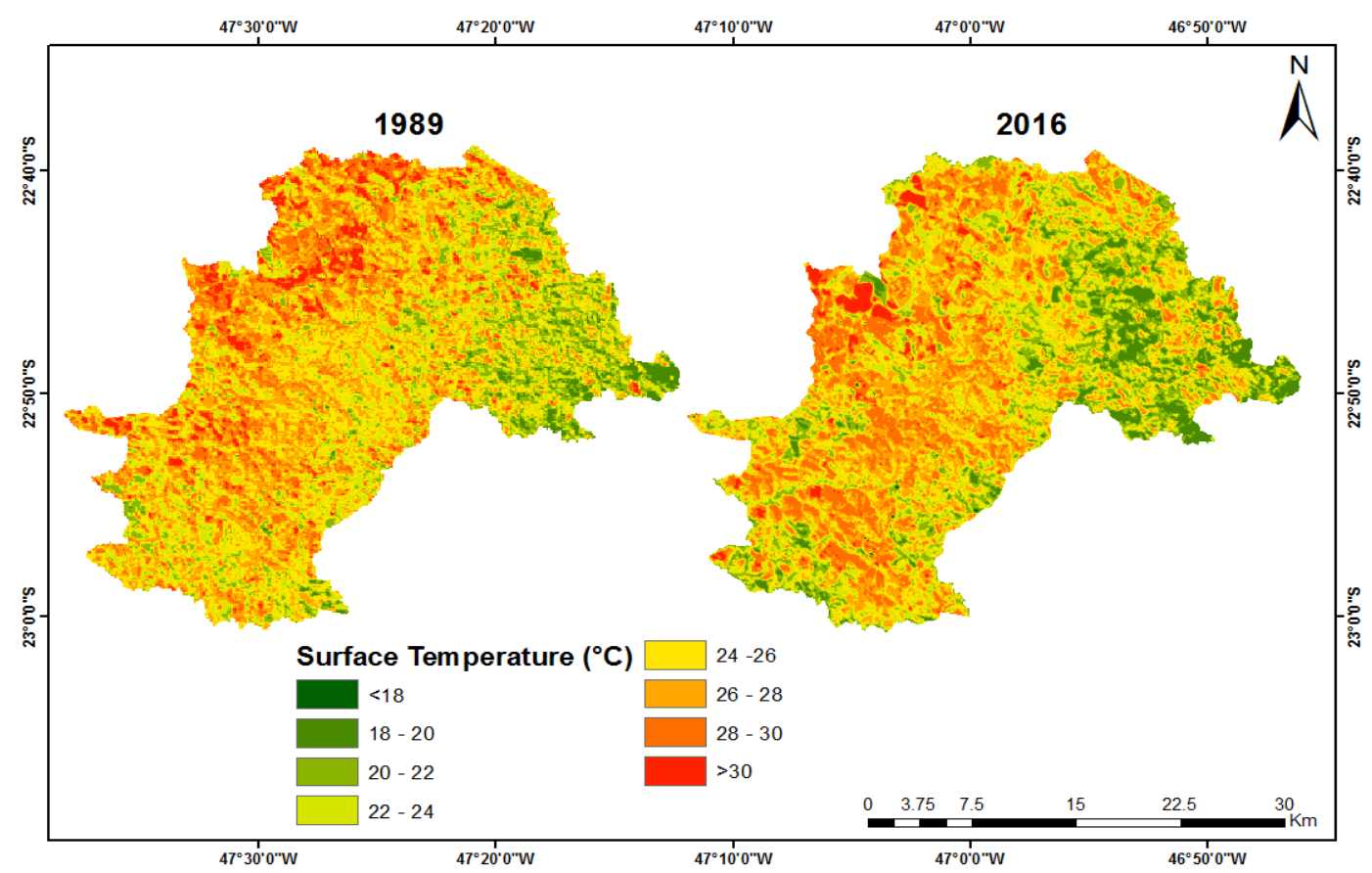

Figure 3 - Spatial variability of surface temperature in Campinas on August 14th 1989 and September 09th 2016.

\subsection{MAXIMUM TEMPERATURES THRESHOLD IN CAMPINAS'S WEATHER STATIONS}

The Cepagri station presented the highest number of days for each maximum temperature threshold proposed (Figure 4), based on the analyses conducted with air temperature data obtained from the three meteorological stations (Figure 5 to 7). The result validates the previous analysis of LULC, in which Cepagri station suffered most changes in its surroundings, almost tripling its urban area. Although the weather station in Viracopos Airport showed larger variations in surface temperature, the station was the second with an altered environment, presenting fewer days with maximum temperature when compared to Cepagri. 


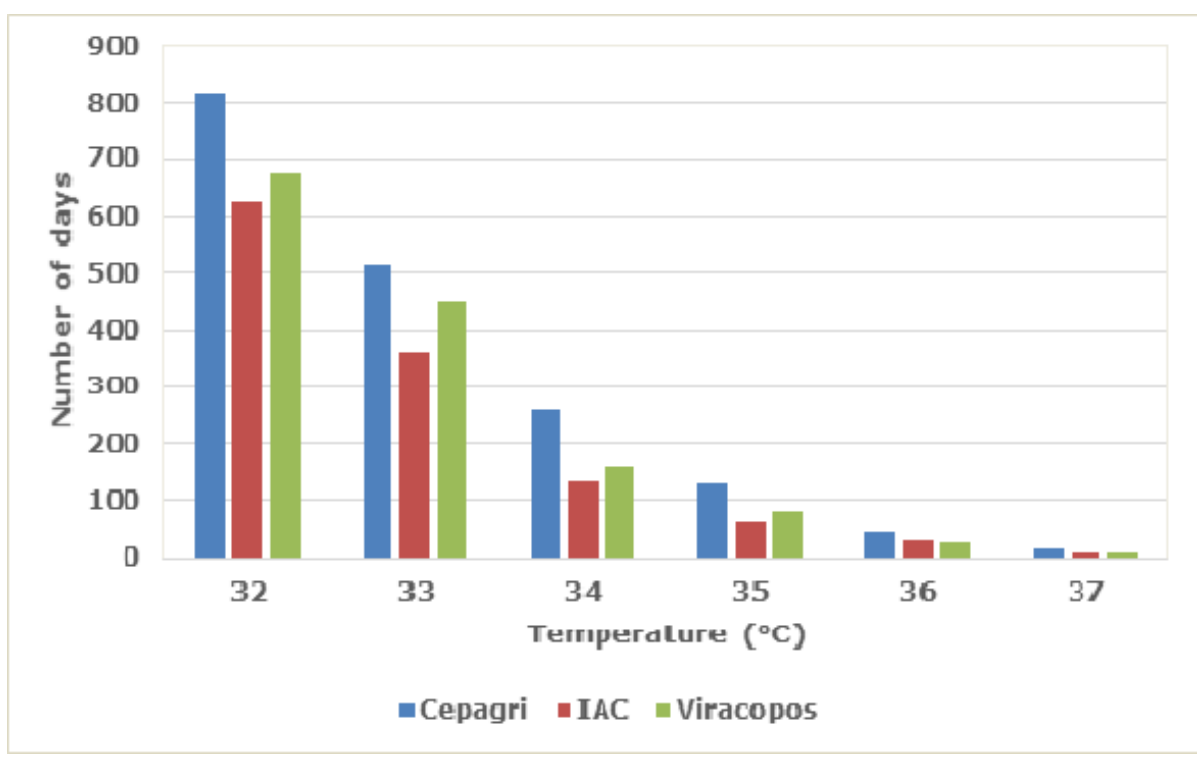

Figure 4 - Comparative value of maximum temperature threshold in Campinas weather stations



Figure 5 - Air Temperature $\left({ }^{\circ} \mathrm{C}\right)$ at Cepagri Weather Station. 


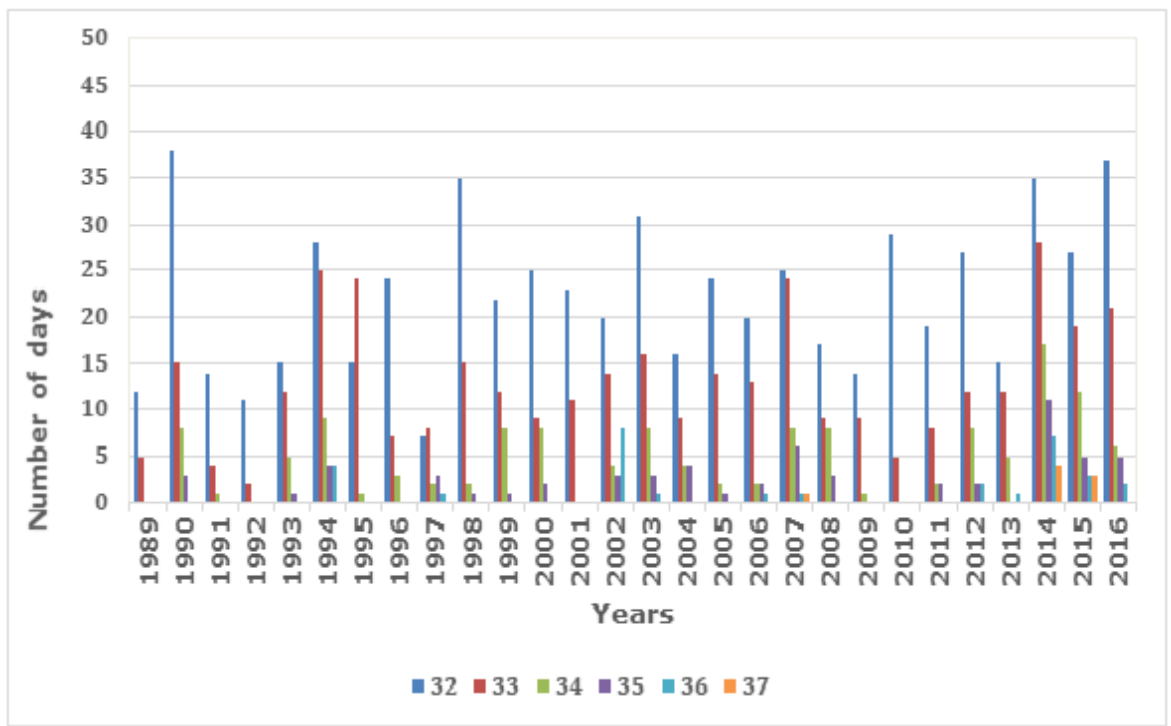

Figure 6 - Air Temperature $\left({ }^{\circ} \mathrm{C}\right)$ at IAC Weather Station.

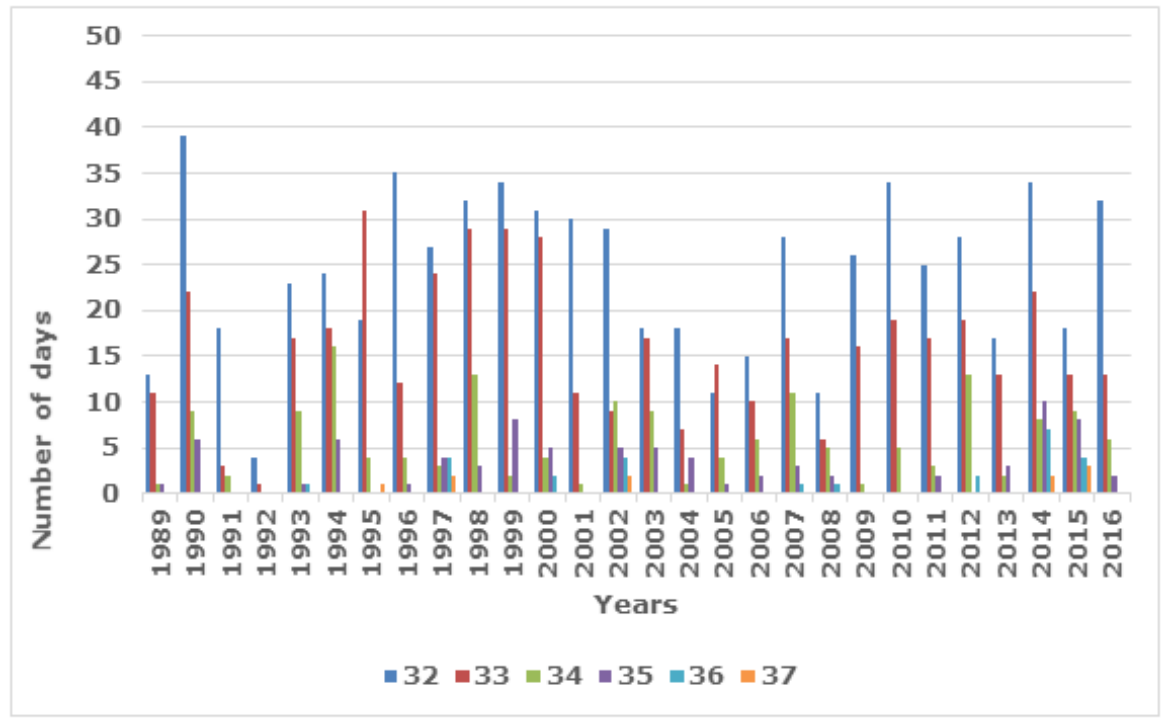

Figure 7 - Air Temperature $\left({ }^{\circ} \mathrm{C}\right)$ at Viracopos Airport Weather Station.

The results indicate consistent relations between the increased urbanized area and the elevation of air and surface temperature in Campinas. Azevedo et al. (2016) quantifying the Daytime and Night-Time Urban Heat Island in Birmingham-UK, highlights in their results that the Urban Heat Island surface is related to land use and occupation.

The temperature increasing trend may be related to changes in land use and occupation, as well as to urbanization, influencing the local climate (DUFEK and AMBRIZZI, 2006). The studies developed by Blain (2009) showed a trend of increase in air temperature in Campinas-SP - the author used one long time series from IAC, from 1989 to 2007.

According to Oke (1987), the physical justification for the results may be the low moisture content in urban area, that shifts the energy balance on the 
surface towards the sensible heat, under condition of decreased air humidity This anthropic effect can intensify the heat island in the cities and reinforce climatic changes provoked by global warming (ROTH, 2007). Blain (2010) highlights that the time series in Sao Paulo state recorded the highest temperatures in dry years. The energy available for sensible heat may promote higher values of air temperature, as observed in each meteorological station studied

\section{CONCLUSIONS}

By mapping the LULC changes around the three meteorological stations in the municipality of Campinas, we identified an increase in the urbanized area, validating the premise that urban expansion can be related to the increase in temperature of air and surface for the years 1989 and 2016.

The Cepagri weather station presented the highest air temperatures, followed by Viracopos station. The result may be related to the evolution of land use and occupation, since Cepagri station also presented the greatest changes in urban areas, increasing from $10.3 \%$ in 1989 to $32 \%$ in 2016 . However, we observed a higher spatial temperature variability around Cepagri station in 2016, when compared to 1989. In 1989, the surface temperature was between $28^{\circ} \mathrm{C}$ and $30^{\circ} \mathrm{C}$, and in 2016 , the temperature ranged from $30^{\circ} \mathrm{C}$ to $24^{\circ} \mathrm{C}$. This fact may be related to the moving of the meteorological station to a near and greener area. Yet, the surface temperature presented expressive variation in the region where Viracopos meteorological station is located, portraying an increased air temperature between 1989 and 2016, combined with an expressive expansion of the urban area, from $16,7 \%$ in 1989 to $27 \%$ in 2016 , with surface temperatures increasing about $4^{\circ} \mathrm{C}$ between the two analysed years.

The present research showed that there are consistent relations between the expansion of urban areas and the increase of air and surface temperatures in Campinas, based on data collected around the three meteorological stations installed in the city. We can state that the urbanization process occurring through the intense modification of land use and occupation patterns may influence the local micro-climate, increasing temperature in the analysed area.

\section{REFERENCES}

ANDRADE, A. C.; FRANCISCO, C. N.; ALMEIDA, C. M. Desempenho de Classificadores Paramétrico e não Paramétrico na classificação da fisionomia vegetal. Revista Brasileira de Cartografia, no 66/2, p. 349-363, 2014.

ARNFIELD, J. A. Two decades of urban climate research: a review of turbulence, exchanges of energy and water, and the urban heat island. International Journal of Climatology, n. 23, p. 1-26, 2003

AZEVEDO, J. A.; CHAPMAN, L.; MULLER, C. L. Quantifying the Daytime and Night-Time Urban Heat Island in Birmingham, UK: A Comparison of Satellite Derived Land Surface Temperature and High Resolution Air Temperature Observations. Remote Sens. V. 8, n.153, 2016. 
BLAIN, G. C. et al. Análises estatísticas das tendências de elevação nas series anuais de temperatura mínima do ar no estado de São Paulo. Bragantia, Campinas, v. 68, n. 3, p. 807-815, 2009.

BLAIN, G. C. Precipitação pluvial e temperatura do ar no Estado de São Paulo: periodicidades, probabilidades associadas, tendencias e variaç̃oses climáticas. Piracicaba: Escola Superior de Agricultura "Luiz de Queiroz", 2010, 194 p.

BECK, H. E.; ZIMMERMANN, N. E.; MCVICAR, T. R.; VERGOPOLAN, N.; BERG, A.; WOOD, E. F. Present and future köppen-geiger climate classification maps at 1-km resolution. Scientific Data, v. 5, p. 1-12, 2018

CAIADO, M. C. S.; PIRES, M. C. S. Campinas metropolitana: transformações na estrutura urbana atual e desafios futuros. In: CUNHA, J. M. P. da (Org.). Novas metrópoles paulistas: população, vulnerabilidade e segregação. Campinas: Nepo/Unicamp, 2006, p. 275-304.

CAMPINAS. Dados do munícipio e RMC. Disponível em <http://www.campinas.sp.gov.br/governo/seplama/dadosdomunicipio/cidade/> Acesso em: 04 de junho de 2017, às 10h.

CAVALCANTI, I. F. A.; NUNES, L. H.; MARENGO, J. A.; GOMES, J. L.; SILVEIRA, V. P.; CASTELLANO, M. S. Projections of Precipitation Changes in Two Vulnerable Regions of Sao Paulo State, Brazil. American Journal of Climate Change, 6, p. 268-293, 2017.

CHEN, X. L.; ZHAO, H. M.; LI, P. X.; YIN, Z. Y. Remote sensing image-based analysis of the relationship between urban heat island and land use/cover changes. Remote Sensing of Environment, 104, p. 133-146, 2006.

DIAS, M. A. S., DIAS, J., CARVALHO, L. M. V., FREITAS, E. D.; DIAS, P. L. S. Changes in extreme daily rainfall for São Paulo, Brazil. Climatic Change. V. 116 n. 3, 705-722, 2013.

DUFEK, A. S.; AMBRIZZI, T. Variabilidade climática da temperatura no Estado de São Paulo. In: Congresso Brasileiro de Meteorologia, Florianópolis, 2006.

FU, P.; WENG, Q. A time series analysis of urbanization induced land use and land cover change and its impact on land surface temperature with Landsat imagery. Remote Sensing of Environment, 175, p. 205-214, 2016.

IBGE. Instituto Brasileiro de Geografia e Estatística - Campinas/SP. Available in <http://cidades.ibge.gov.br/painel/painel. php?codmun=350950> Accessed in: June, 6th, 2017.

IBGE. Manual Técnico do Uso da Terra. 30 edição, 2013. Available in < http://biblioteca.ibge.gov.br/visualizacao/livros/liv81615.pdf> Accessed in: July 8th, 2016.

INPE. Instituto Nacional de Pesquisas Espaciais. Available in < Catálogo de Imagens (inpe.br)> Accessed in: January 10th, 2015.

LO, C. P.; QUATTROCHI, D. A. Land-use and land-cover change, urban heat island phenomenon, and health implications: A remote sensing approach. Photogrammetric Engineering and Remote Sensing, 69 (9), p. 1053-1063, 2003. 
OKE, T. R.; MILLO G.; CHRISTEN A.; VOOGHT J. A.; Urban climates. Cambridge University Press; 1st edition, 2017, 548p.

OKE, T. R. Boundary Layer Climates. London: Routledge, 1987, 435 p.

OLIVEIRA, T. H.; GALVÍNCIO, J. D.; PIMENTEL, R. M. M; DA SILVA, B. B. Uso e cobertura do solo e seus efeitos na distribuição da temperatura de superfície em área urbana. Revista Brasileira de Geografia Física, v.06, n.06, p. 1598-1616, 2013.

PEZZUTO, C. C. Avaliação do ambiente térmico nos espaços urbanos abertos. Estudo de caso em Campinas, SP. 2007. Campinas: Universidade Estadual de Campinas, 2007, 182 p.

RODRIGUES, M.; DUPAS, F. A.; REBOITA, M. S. Temperatura Aparente de Superfície na Bacia Hidrográfica do Rio Tavares, Florianópolis. Revista Brasileira de Climatologia, v. 21, p. 1-19, 2017.

USGS. United States Geological Survey. Available in <https://www.usgs.gov/products/multimedia-gallery/images > Assessed in: March, 25th, 2017.

VOOGT, J. A., OKE, T. R. Effects of urban surface geometry on remotely sensed surface temperature. International Journal of Remote Sensing, v. 19, n. 5, p. 895-920, 1998.

VOOGT, J. A., \& OKE, T. R. Thermal remote sensing of urban climates. Remote Sensing of Environment, 86, 370-384, 2002.

WENG, Q. A remote sensing-GIS evaluation of urban expansion and its impact on surface temperature in the Zhujiang Delta, China. International Journal Remote Sensing, 22, p.1999-2014, 2001.

WENG, Q.; LU, D.; SCHUBRING, J. Estimation of land surface temperaturevegetation abundance relationship for urban heat island studies. Remote Sensing of Environment, 89, p.467-483, 2004.

YUAN, F.; BAUER, M. E. Comparison of impervious surface area and normalized difference vegetation index as indicators of surface urban heat island effects in Landsat imagery. Remote Sensing of Environment, 106, p.375-386, 2006.

ZHOU, W.; HUANG, G.; CADENASSO, M. L. Does spatial configuration matter? Understanding the effects of land cover pattern on land surface temperature in urban landscapes. Landscape and Urban Planning, 102, p. 54-63, 2011.

ZHU, Z.; WOODCOCK, C.E. Continuous change detection and classification of land cover using all available Landsat data. Remote Sensing of Environment, 144 , p. $152-171,2014$ 